\title{
Self-healing processes in nature and engineering: self-repairing biomimetic membranes for pneumatic structures
}

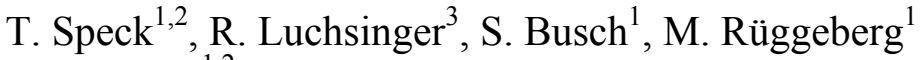 \\ \& O. Speck ${ }^{1,2}$ \\ ${ }^{1}$ Botanic Garden, University of Freiburg, Freiburg, Germany \\ ${ }^{2}$ Competence Networks Biomimetics and BIOKON \\ ${ }^{3}$ Prospective Concepts ag, Glattbrugg, Switzerland
}

\begin{abstract}
Self-repairing processes in plants sealing fissures caused by natural growth processes (e.g. in the vine Aristolochia macrophylla) or by artificial injuries (e.g. in the common bean Phaseolus vulgaris) serve as concept generators for the development of a biomimetic coating for membranes of pneumatic structures based on the Tensairity ${ }^{\circledR}$ concept. First results with foam-based biomimetic selfrepairing coatings for technical membranes are very promising. For lesions with nails of up to $5 \mathrm{~mm}$ diameter, reductions of the air-leakage of two to three orders of magnitude could be achieved.
\end{abstract}

Keywords: self-healing, vines, biomimetics, self-repairing membranes, pneumatic structures, Tensairity ${ }^{\circledR}$.

\section{Introduction}

Over the last two decades, plants have proved to be a real treasure trove as models for the construction of biomimetic technical structures and materials $[1,2]$. One example are self-healing processes which are very common in nature. Self-repair is still uncommon in technical products but especially over the last few years some interesting solutions for special applications have been presented [3-7]. Plants have evolved an amazing capacity to seal and mend internal fissures caused by growth processes and wounds effected by artificial external injuries. For analytically describing the (fast) self-repair characteristics of the 
parenchyma, vine (e.g. Aristolochia) and herbaceous plants (e.g. Phaseolus, Ricinus) are used as model organisms. These plants react to fissures and ruptures in their peripheral tissues by a rapid repair mechanism, which seals the lesion very effectively and secures the functional integrity of the plant stem.

\section{Biological templates}

Vines of the genus Aristolochia proved to be especially suitable models for quantitatively studying self-repair processes caused by internal secondary growth as they exhibit very efficient rapid repair mechanisms in their stems. The Dutchman's Pipe (Aristolochia macropyhlla) was chosen as model species as stem mechanics and functional anatomy of this species were extensively examined during the last years [8]. In young, one year old stem parts, this plant possesses a closed ring of sclerenchyma fibres in the stem periphery, fig. $1 \mathrm{~A}$.

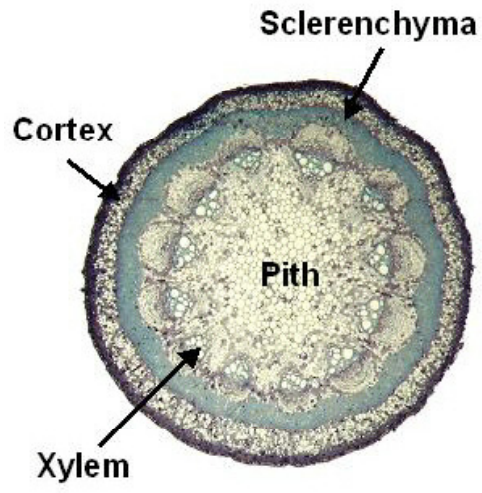

A

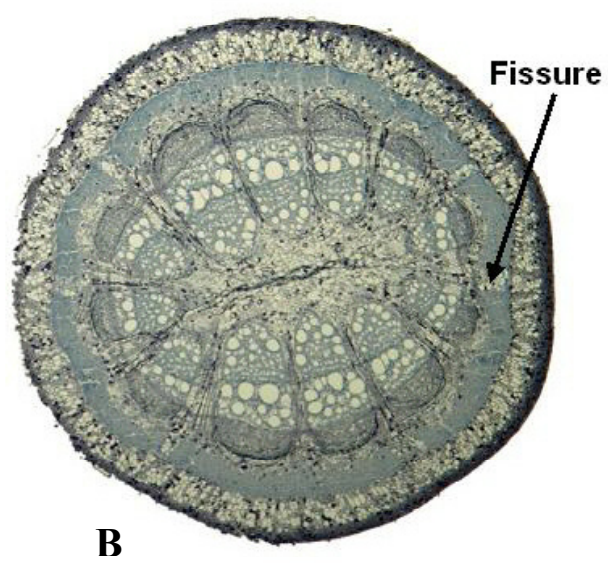

Figure 1: Cross-sections of stems of the vine Aristolochia macrophylla. (A) Tissue distribution in a one year old stem with closed peripheral ring of lignified strengthening tissue (sclerenchyma fibres). (B) As a consequence of secondary growth a two year old stem shows an increase in the amount of vascular tissues (especially of xylem) and a segmentation of the peripheral sclerenchymatous ring.

This tissue causes the high bending stiffness found in young Aristolochia stems. When the stems become older, secondary growth processes occur, and the vascular tissues - phloem and especially xylem (wood) both located inside of the sclerenchymatous ring - significantly increase in size. Secondary growth of the vascular tissues causes radial stresses and strains in the soft parenchymatous tissues located between the vascular tissues and the sclerenchymatous ring and tangential stresses and strains in the sclerenchymatous ring. When the stresses 
and strain more and more increase due to continuous secondary growth, the sclerenchymatous ring finally ruptures and splits into segments, fig. 1B. The fissures typically run through the middle lamellas of neighbouring sclerenchyma cells [9]. A. macrophylla seals these lesions very effectively by a rapid repair mechanism and secures the functional integrity of the plant structure.

The repair process can be subdivided in at least four phases. The first phase (on which we concentrate in our biomimetic approach) is based on fast straintriggered deformation processes of pressurized parenchyma cells that swell into the fissure and seal it, fig. 2A. We hypothesize, that this first phase of fissure repair is mainly caused by viscoelastic-plastic deformation of the internally pressurised (turgescent) parenchyma cells. In how far cell wall mechanics in a second phase of fissure repair are changed due to a process of hydroxyl-radical induced cell wall loosening ('plastification'), recently described for growing cells $[10,11]$, is subject of ongoing projects. In the third phase of repair when the fissure extends deeply into the sclerenchymatous ring, the repairing cells start to divide mainly tangentially. Later in this phase the fissure runs through the sclerenchyma ring, and the repairing cells show significant radial and tangential cell division, fig. 2B. In some fissures the repairing cells may remain entirely parenchymatous. In other fissures a fourth phase can be discerned in which the walls of the most peripheral sealing cells increase in thickness and start to lignify, fig. $2 \mathrm{C}$. Through this the mechanical function of the sclerenchyma ring can be - at least - temporarily restored.
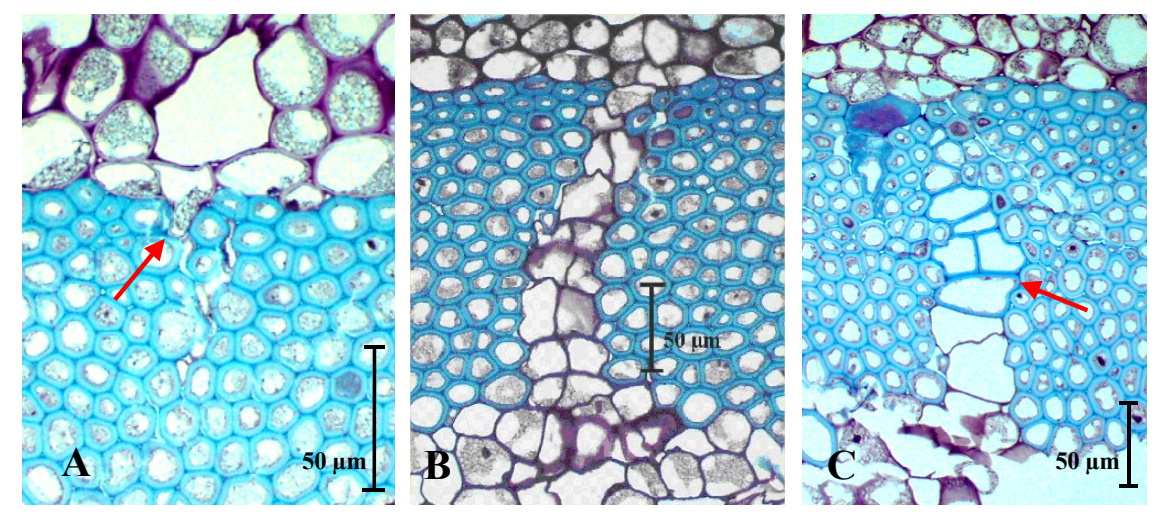

Figure 2: Fissure repair in the vine Aristolochia macrophylla. (A) An adjacent parenchyma cell expands into a small fissure in the sclerenchymatous ring (phase I), see arrow. (B) A broad fissure in the scleremchyma ring is sealed by parenchymatous repairing cells having the typical irregular shape (phase III). (C) The walls of peripheral repair cells are thickened and lignified (phase IV).

Cell shape and cell wall thickness differ remarkably between 'normal' parenchyma cells of the cortex and parenchymatous repairing cells sealing fissures in the sclerenchyma ring. 'Normal' parenchyma cells are round/elliptical 
in cross-section, whereas repairing cells typically posses an irregularly shaped cross-section, allowing a tight sealing of the fissure. Additionally, during the initial phases of fissure repair the cell walls of sealing parenchyma cells become significantly thinner, fig. 2A-B. As a measure of cell shape the ratio of perimeter to cross-sectional area (P/A) was used. For the initial phases of fissure repair preliminary analyses indicate an increase of $\mathrm{P} / \mathrm{A}$ by a factor of 1.4 from $161 \pm 39 \mathrm{~mm}^{-1}$ for 'normal' parenchyma cells to $229 \pm 130 \mathrm{~mm}^{-1}$ for fissuresealing cells. At the same time cell wall thickness decreases by a factor of 1.4 from $1.18 \pm 0.22 \mu \mathrm{m}$ for 'normal' parenchyma cells to $0.87 \pm 0.37 \mu \mathrm{m}$ for fissure sealing cells. The most parsimonious explanation is that the cross-sectional area (and the volume) of individual cells remains constant (i.e. no cell wall biosynthesis takes place) when the cells change in shape in the first phase of fissure repair. In this case both factors are expected to be nearly identical, since the existing cell wall material is merely rearranged. For a more detailed discussion of this phenomenon we refer to Speck et al. [9]. We suggest that the initial phases of fissure repair take place without cell division and (significant) cell wall biosynthesis, but involve mainly physical-chemical reactions of the parenchyma cells to a perturbation of the local stress-strain-field caused by the lesion. This result is encouraging for a transfer of this fast repair mechanism into biomimetic solutions for technical applications.

Similar processes as described in Aristolochia macrophylla for fissures caused by growth processes are found in the hypocotyls of herbaceous plants (e.g. Phaseolus, Ricinus, Helianthus) during the (fast) self-repair taking place as a reaction to wounds effected by artificial external injuries, fig. 3 .
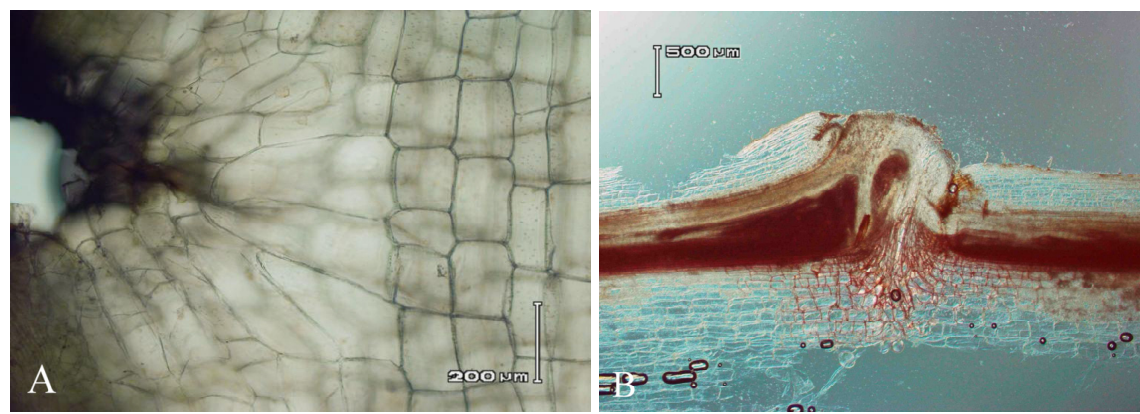

Figure 3: Fissure repair after an artificial external injury in Common Bean (Phaseolus vulgaris). (A) Early phase of self-repair, parenchyma cells expand into the artificial injury. (B) Late phase of self-repair, the lesion is entirely sealed by a callus of newly formed thickened (often lignified) repair tissue.

\section{Technical applications}

In cooperation with the Swiss company prospective concepts ag, biomimetically inspired self-repair functions are transferred into technical membranes of ultra- 
light pressurized beams based on the Tensairity ${ }^{\circledR}$ concept. This technology represents a combination of cylindrical membranes filled with compressed air under moderate overpressure and supporting struts and cables, fig. 4. This technology yields ultra-light deployable structures as strong as steel [12-15].
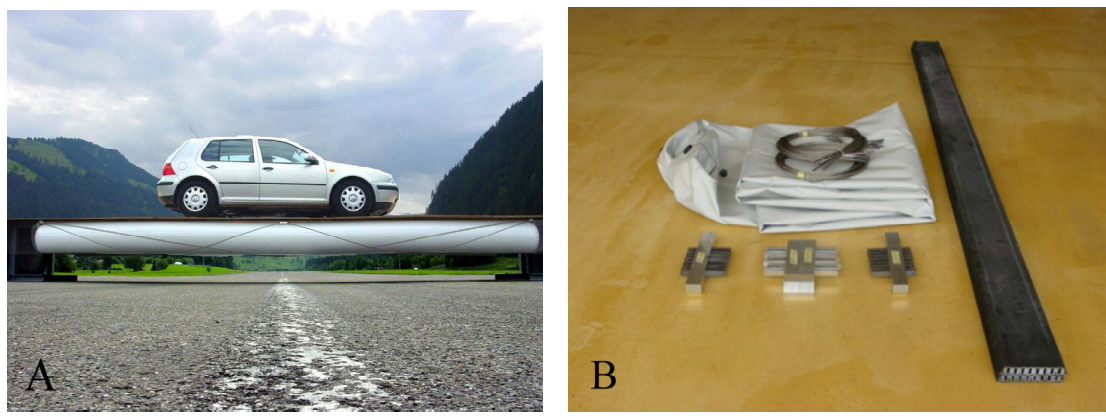

Figure 4: $\quad$ (A) Tensairity ${ }^{(B)}$ demonstration bridge with $8 \mathrm{~m}$ span and 3.5 tons maximal load. (B) Components of the Tensairity ${ }^{(\mathbb{R}}$ demonstration bridge showing the non-inflated cylindrical membrane
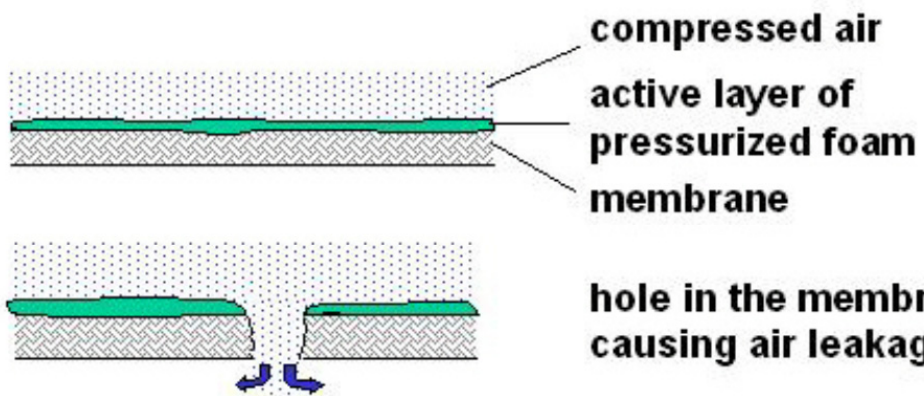

hole in the membrane causing air leakage

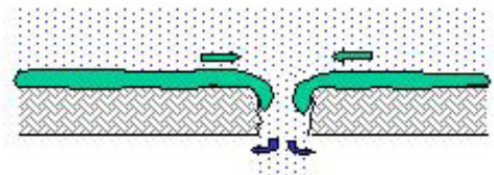
sealing of the hole
due to expansion of
the active layer

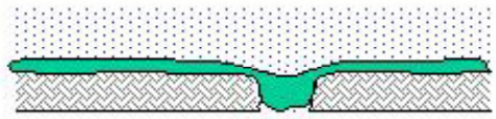

hole sealed and air leakage stopped

Figure 5: Functional model for a self-repairing technical membrane.

One shortcoming of all pneumatic structures is the vulnerability of the membrane to tearing and puncturing which cause a drop in the internal pressure 
and a subsequent reduction of the load-carrying capacity of the beams. Tensairity ${ }^{\circledR}$ technology is much less jeopardised by holes than other (high pressure) pneumatic structures as the air beam mainly acts as distance piece to prevent the buckling of compression elements. The main load bearing elements are the cables and compression struts. Tensairity ${ }^{\circledR}$ technology works with moderate overpressure in the range of 50 to 500 mbar and compressors or fans are used to adjust the internal pressure to variable environmental conditions. Because of the moderate overpressure, the compressors or fans can also cope with air leakage due to small holes. Nevertheless a self-repairing function will significantly improve the market prospects of this new technology.

In order to transfer ideas based on the first phase of fast self-repair in plants into a biomimetic 'self-healing' membrane for Tensairity ${ }^{\circledR}$ beams a functional model was developed, fig. 5. The basic idea is to develop a 'foamy' layer made of a pressurized cellular technical material that biomimicks the self-repair mechanism in plants. This biomimetic material is used as an inner coating of the membrane and if the membrane is punctured, the foamy repair layer seals the hole as the foam cells - like the parenchyma cells in the biological template expand into the hole due to their internal pressure and to surface tension effects occurring in the prestrained foam. In a first approach polyurethane-foam was used for the biomimetic coating of the self-repairing membrane.

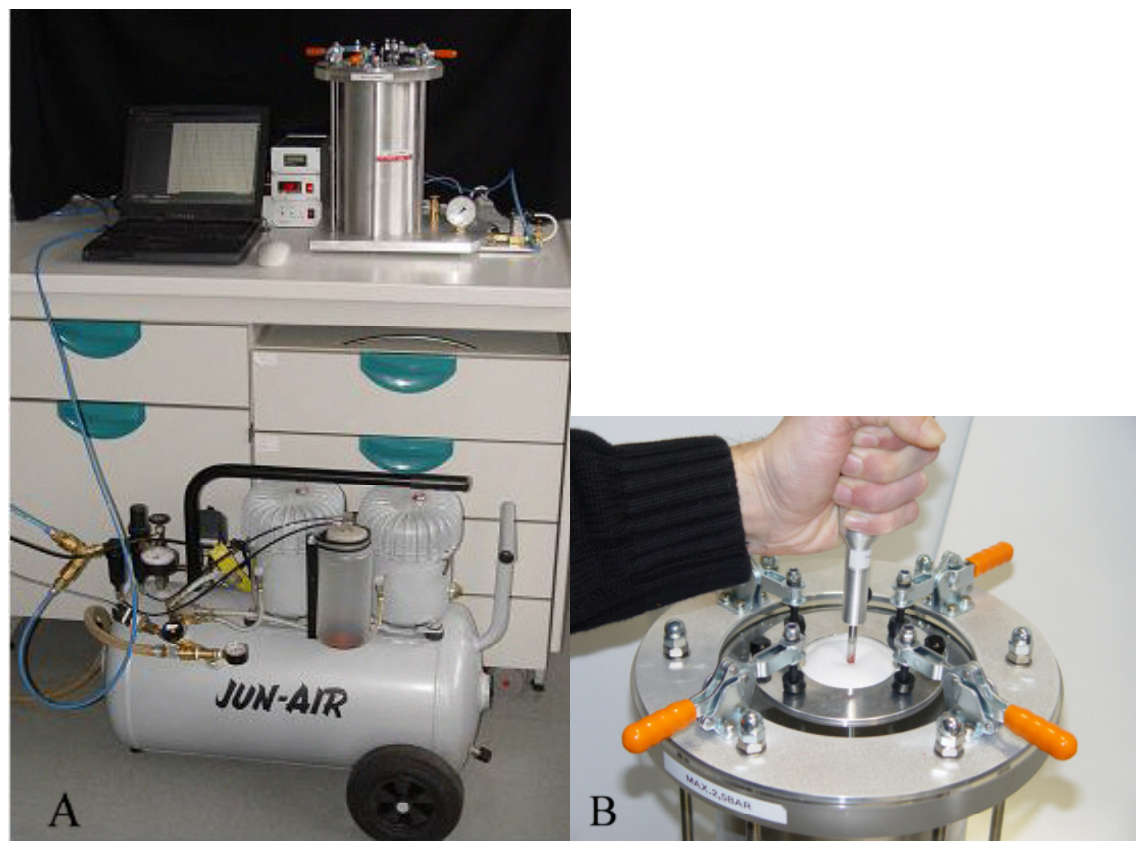

Figure 6: (A) Experimental set-up for testing the self-repair quality of coated membranes. (B) Puncturing of a coated membrane with a nail of $5 \mathrm{~mm}$ diameter. 

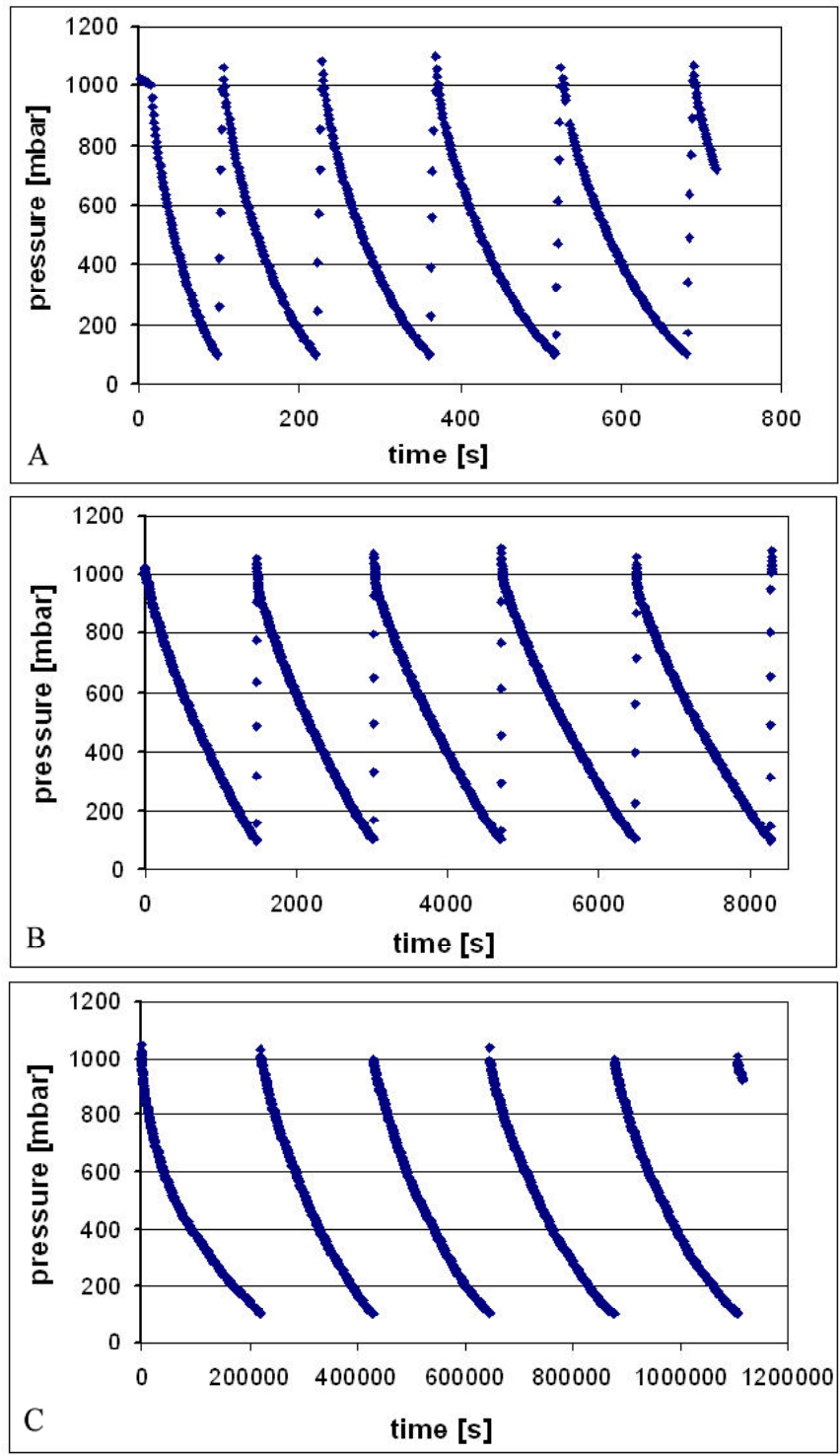

Figure 7: Graphs showing the duration of pressure drop from 1000 mbar to 100 mbar for membranes punctured with a nail of $2.6 \mathrm{~mm}$ diameter. (A) Uncoated membrane; mean duration of pressure drop: 130 seconds. (B) Membrane coated with a biomimetic foam polymerised under ambient pressure; air-leakage reduced by about one order of magnitude. (C) Membrane coated with a biomimetic foam polymerised under overpressure; air-leakage reduced by three orders of magnitude. 
In order to test the self-repair quality of different biomimetic coatings an experimental set-up was developed that allows to measuring how long a defined pressure drop takes for specific types of lesions in uncoated and coated membranes. The ratio of duration in a coated membrane over duration in an uncoated membrane was defined as repair factor. As higher the repair factor is as better the self-repair function of a given coating is. The experimental set-up consists of a pressure cylinder in which membranes with and without coating can be clamped, fig. 6 .

The overpressure is maintained by means of a supercharger. The set-up is computer controlled as well as to the execution of the tests as to data storage. We have chosen a test protocol in which the cylinder is pressurized up to $1000 \mathrm{mbar}$ and the time is measured until the pressure is dropped down to $100 \mathrm{mbar}$. When the upper pressure limit is reached the control programme automatically switches off the supercharger, when the lower limit is reached the supercharger is switched on. This allows consecutive measurements of the duration of the predefined pressure drop for a given type of lesion and membrane coating.

Pilot studies with self-repairing foam-based biomimetic membrane coatings have produced highly promising results. These biomimetic coatings are able to reduce significantly the air-leakage of the pneumatic structure after puncturing of the membrane by nails of up to $5 \mathrm{~mm}$ diameter. With biomimetic coatings based on polyurethane foam polymerised under ambient pressure air-leakage can be reduced by about one order of magnitude, i.e. repair factors of 10 are found. With biomimetic foam based coatings polymerised under overpressure airleakage can be reduced by two to three orders of magnitude, fig. 7 .

Technical applications of self-repairing processes inspired by biological templates are obviously not limited to the application to Tensairity ${ }^{\circledR}$ structures or other pneumatic structures but can be realised with other types of biomimetic self-repairing materials for many applications in industry, clothing and medical technology.

\section{Acknowledgements}

The project was supported by the Ministerium für Wissenschaft, Forschung und Kunst des Landes Baden-Württemberg within the framework of the Kompetenznetz, Pflanzen als Ideengeber für die Entwicklung biomimetischer Materialien und Technologien' and by the INTERREG III Programm (BioValley).

\section{References}

[1] Speck, T. \& Spatz, H-Ch., Transkription oder Translation: Pflanzen als Ideengeber für neue Materialien und technische Leichtbaustrukturen. BIONIK - Ökologische Technik nach dem Vorbild der Natur, ed. A. von Gleich, Teubner-Verlag: Stuttgart, 2. ed., pp. 229-245, 2001. 
[2] Speck, T. \& Neinhuis, C., Bionik, Biomimetik - ein interdisziplinäres Forschungsgebiet mit Zukunftspotential. Naturwissenschaftliche Rundschau, 57(4), pp. 177-191, 2004.

[3] Gerl, B. \& Sterbak, R., Eine tragende Rolle: Ein ausgeklügelter Materialmix hält Fahrzeuge sicher in der Spur. Spektrum der Wissenschaft, 1, pp. 42-43, 2005.

[4] White, S.R., Sottos, N.R., Geubelle, P.H., Moore, J.S., Kessler, M.R., Sriram, S.R., Brown, E.N. \& Viswanathan, S., Autonomic healing of polymer composites. Nature, 409, pp. 794-797, 2001.

[5] Kessler, M.K., Sottos, N.R. \& White, S.R., Self-healing structural composite material. Composites Part A: Applied Science and Manufacturing, 34, pp. 743-753, 2003.

[6] Pang I.W.C. \& Bond I.P, 'Bleeding composites' - Damage detection and self-repair using a biomimetic approach. Composites Part A: Applied Science and Manufacturing, 36, pp. 183-188, 2004.

[7] Pang, J. \& Bond, I.P., A hollow fibre reinforced polymer composite encompassing self-healing and enhanced damage visibility. Composites Science and Technology, 65, 1791-1799, 2005.

[8] Speck, T., Rowe, N.P., Civeyrel, L., Claßen-Bockhoff, R., Neinhuis, C. \& Spatz, H.-Ch., The potential of plant biomechanics in functional biology and systematics. Deep Morphology: Toward a Renaissance of Morphology in Plant Systematics, eds. T. Stuessey F. Hörandl \& V. Mayer V., Koeltz: Königstein, pp. 241-271, 2004.

[9] Speck, T., Masselter, T., Prüm, B., Speck, O., Luchsinger, R. \& Fink, S., Plants as concept generators for biomimetically technical light-weight structures with variable stiffness and self-repair mechanism. Journal of Bionics Engineering, 1(4), pp. 199-205, 2004.

[10] Schopfer, P., Hydroxyl radical-induced cell-wall loosening in vitro and in vivo: implications for the control of elongation growth. The Plant Journal, 28, pp. 679-688, 2001.

[11] Liszkay, A., van der Zalm, E. \& Schopfer, P., Production of reactive oxygen intermediates $\left(\mathrm{O}_{2}{ }^{-}\right), \mathrm{H}_{2} \mathrm{O}_{2}$, and $\mathrm{OH}$ ) by maize roots and their role in wall loosening and elongation growth. Plant physiology, 136, pp. 3114 3123, 2004.

[12] Luchsinger, R.H., Pedretti, M. \& Reinhard, A., Pressure induced stability: from pneumatic structures to Tensairity. Journal of Bionics Engineering, 1(3), pp. 141-148, 2004.

[13] Luchsinger, R.H., Pedretti, A., Steingruber, P. \& Pedretti, M., The new structural concept Tensairity: Basic Principles. Progress in Structural Engineering, Mechanics and Computation, ed. A. Zingoni, A.A. Balkema Publishers: London, 2004.

[14] Luchsinger, R.H., Pedretti, A., Steingruber, P. \& Pedretti, M., Light weight structures with Tensairity. Shell and Spacial Structures from Models to Realization, ed. R. Motro, Editions de l'Espéro: Montpellier, 2004. 
114 Design and Nature III: Comparing Design in Nature with Science and Engineering

[15] Luchsinger, R.H., Crettol, R., Steingruber, P., Pedretti, A. \& Pedretti, M., Going strong: from inflatable structures to Tensairity. Textile composites and inflatable structures II, eds. E. Onate \& B. Kröplin, CIMNE: Barcelona, 2005. 